\title{
LAirA - współpraca na rzecz poprawy dostępności lotnisk transportem niskoemisyjnym
}

\section{Karolina Kamińska, Maciej Sulmicki}

LAirA (Landside Airports Accessibility - Dostępność lądowa lotnisk) to projekt realizowany od maja 2017 r. w ramach programu Interreg Europa Środkowa. Jednym z partnerów projektu jest Samorząd Województwa Mazowieckiego, którego Zarząd powierzył realizację projektu Mazowieckiemu Biuru Planowania Regionalnego.

Projekt LAirA skupia się na wyzwaniach związanych z zapewnieniem multimodalnej dostępności lądowej lotnisk Europy Środkowej, tak by stanowiły one element zintegrowanego, inteligentnego i niskoemisyjnego systemu transportowego. Celem projektu jest ograniczenie zużycia energii i negatywnego wpływu na środowisko, wynikających z funkcjonowania lotnisk i ich zapleczy. Cel ten ma zostać osiągnięty poprzez wpłynięcie na zachowania komunikacyjne pracowników lotnisk i pasażerów, jak też opracowanie nowatorskich strategii dla podmiotów publicznych w zakresie planowania niskoemisyjnej mobilności. Projekt LAirA obejmuje siedem głównych obszarów tematycznych: mobilność elektryczną, połączenia lotniczo-kolejowe, ruch pieszy i rowerowy, mobilność współdzieloną, inteligentne systemy transportowe, planowanie podróży i publiczny transport drogowy.

Mazowieckie Biuro Planowania Regionalnego odpowiedzialne jest m.in. za przeprowadzenie analiz dotyczących mobilności w obszarze funkcjonalnym lotniska Warszawa-Modlin, które posłużą do opracowania strategii zintegrowanego systemu obejmującego lotnisko i jego obszar funkcjonalny. Wśród dotychczasowych rezultatów pracy w ramach projektu można wymienić opracowanie pt. Analiza stanu istniejącego multimodalnego systemu mobilności obszaru funkcjonalnego lotniska Warszawa-Modlin. Przedmiotowy obszar obejmuje gminy Nowy Dwór Mazowiecki, Zakroczym i Pomiechówek, lecz z uwagi na istotną rolę Warszawy w funkcjonowaniu lotniska, w analizie uwzględniono również połączenia komunikacyjne ze stolicą. Rezultaty badań przedstawione zostały na pierwszym spotkaniu z interesariuszami obszaru lotniskowego, w tym samorządami lokalnymi i firmami działającymi na terenie lotniska. Kolejnym zadaniem, realizowanym w ramach projektu, są badania ankietowe prowadzone wśród pasażerów i pracowników lotniska na temat ich mobilności. Wyniki badań posłużą do zrozumienia aktualnych zachowań i potrzeb w zakresie mobilności, co powinno pomóc w przewidywaniu przyszłych oczekiwań w tym zakresie oraz ułatwić korzystne kształtowanie zachowań komunikacyjnych pasażerów i pracowników lotniska. 
Projekt LAirA jest realizowany dzięki współfinansowaniu w ramach programu współpracy transnarodowej Unii Europejskiej Interreg Europa Środkowa, wspierającego współpracę ponad granicami. Czas realizacji projektu wynosi 30 miesięcy (do października 2019 r.), budżet całkowity to 2,23 miliony euro, w tym 1,84 miliona stanowi dotacja z Europejskiego Funduszu Rozwoju Regionalnego. Projekt realizowany jest przez 10 partnerów i 5 partnerów stowarzyszonych. Partnerem wiodącym jest XVIII Dzielnica Budapesztu. Pozostali partnerzy - poza Samorządem Województwa Mazowieckiego - to:

- Lotnisko Budapeszt,

- Lotnisko Bolonia,

- Agencja Promocji Gospodarczej Regionu Stuttgart,

- Lotnisko Dubrownik,

- Agencja Rozwoju Miasta Dubrownik,

- Konferencja Regionów Lotniskowych (ARC),

- AustriaTech - Federalna Agencja na rzecz Rozwiązań Technologicznych,

- Urząd Miasta Poznania.

Istotną rolę odgrywają też partnerzy stowarzyszeni, wspierający projekt swą wiedzą i doświadczeniem. Partnerem stowarzyszonym z Mazowsza jest Lotnisko Warszawa-Modlin. Pozostali partnerzy stowarzyszeni to:

- Region Stuttgart,

- SRM - Sieci i Mobilność (Zarząd Transportu Miejskiego w Bolonii),

- Lotnisko Wiedeń,

- BKK - Centrum na rzecz Budapesztańskiego Transportu.

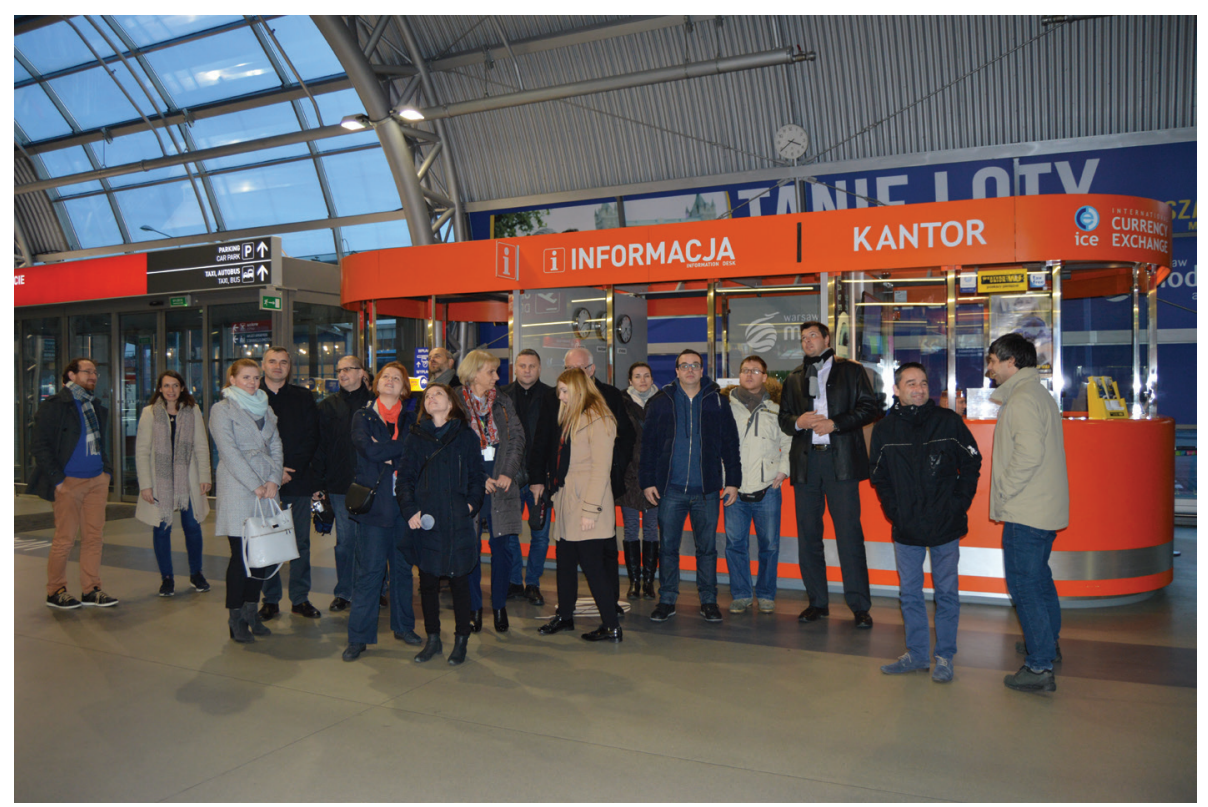

Spotkanie partnerów projektu 22-24 listopada 2017 r. 